\title{
THE ROLE OF BRAND TRUST IN MEDIATING THE CORRELATION BETWEEN THE USE OF CELEBRITY ENDORSERS AND ONLINE CONSUMER PURCHASE INTENTIONS
}

\author{
Sumartini Ade Ruly, Martini Ni Putu Riski, Mandasari I.A. Cynthia Saisaria \\ Faculty of Economics and Business, Warmadewa University, Bali, Indonesia \\ *E-mail: aderuly81@gmail.com
}

\begin{abstract}
Since a few years ago, the business development in the food and beverage sector has experienced very significant growth. The restaurant and restaurant industry is still believed to be a form of business that has good prospects, even in times of crisis. However, in the same period many restaurants went out of business, because they were unable to maintain the number of visitors. Success in the food and beverage sector is not only determined by the number of visitors, but is also determined by the ability to increase customer growth. One strategy that can be done is to use Celebgram or Celebrity Endorser and Brand Trust as a mediator. In previous research, it was found that the use of Celebrity Endorser in increasing consumers' purchase intention only had an effect of $28.53 \%$, so it was deemed necessary to add a Brand Trust variable as a mediator which was expected to further increase consumer buying intentions. The population in this study is the community in Denpasar City with the determination of the sample using purposive sampling. The data analysis technique used the PLS data analysis technique. The results of this study found that brand trust is able to mediate the relationship between the use of celebrity endorsers and consumers' intention to buy online so that the use of celebrity endorsers and brand trusts is expected to provide a reference for MSMEs that offer products in the form of food and beverages online. If before the Covid 19 pandemic conditions consumers were still hesitant to buy food and beverage products online, it is hoped that by using celebrity endorsers that display food and beverage products in a real and honest manner, as well as trust in brands, it can increase the purchase intention of consumers who previously were still hesitant to buy food and beverage products online. With an increase in consumer buying intentions, it is also hoped that MSME actors who sell food and beverages online can increase their sales turnover significantly.
\end{abstract}

\section{KEY WORDS}

Celebrity endorser, brand trust, online purchase intention.

Micro, small and medium enterprises (MSMEs) have an important and strategic role for the country's economic growth, both developing and developed countries. The ability of MSMEs to survive during the economic crisis is proof that the MSME sector is part of a fairly resilient business sector. The existence of MSMEs has an important role in improving people's living standards, as well as in economic development in Indonesia, this is supported by the statement of the Governor of Bank Indonesia Agus Martowardojo who stated that MSMEs are considered capable of contributing up to $99 \%$ for economic growth in Indonesia, as well as being able to absorb energy employment by $97 \%$ so that it can contribute about $56 \%$ of gross domestic product. The micro, small and medium business sector chosen by MSME actors is culinary. Business businesses in the culinary field are considered promising because food is one of the basic human needs (Zuari et al, 2013). The establishment of food businesses can help the government to reduce unemployment and absorb labor and at the same time increase the income received by the community, especially MSME business actors. This can be seen from the increasing growth of MSMEs in Indonesia, which is quite dominated by the food and beverage industry. Denpasar as one of the city centers has a fairly rapid development of MSMEs. Based on research from Antara et al, 2011, one of the leading MSMEs in Denpasar City is the processing industry sector, namely screen printing clothes, clothing equipment (mote, lace), food and beverage products, garments, and fish processing \& preservation. 
Since a few years ago, the business development in the food and beverage sector has experienced very significant growth. The restaurant and restaurant industry is still believed to be a form of business that has good prospects, even in times of crisis. As is known, the world is experiencing a pandemic period from the end of 2019 until now. The decline in people's purchasing power during the pandemic caused a decline in the number of consumers in this pandemic due to a decrease in activities outside the home (social distancing) to minimize the spread of the Covid-19 virus. Responding to the corona virus pandemic in the economic and social context it caused, quoted from liputan6.com, Indonesian President Jokowi Widodo continues to ask business actors to take advantage of digital platforms in maximizing their respective businesses. "Even though there is a policy of reducing interaction, I ask business actors, MSME players, to maximize the use of online services," Jokowi said in Jakarta.

In an effort to increase customer growth from a business, an e-marketing strategy is needed that can increase the intention to buy a product. One strategy that can be done is to use Celegram or Celebrity Endorser. This strategy is related to efforts to increase online purchase intention. In the initial survey, it was found that consumers' online purchase intentions still have several obstacles such as the quality (in the form of taste) of food and beverage products that are not in line with expectations, so in this case it is deemed necessary to use celebrity endorsers in increasing online purchase intentions of food products. and beverages offered by MSMEs in Denpasar. Previous research by regarding the effect of using celebrity endorsers on purchase intentions has been carried out in 2020 . From the results of the study it was found that the use of celebrity endorsers as a whole only gave an effect of $28.53 \%$ (the average of the 3 components of celebrity endorsers). This means that if the use of celebrity endorsers is increased by one unit, the intention to buy food and beverage MSME products only increases by $28.53 \%$ (Sumartini, 2020). In online transactions, trust in brand trust is also very important so that efforts to increase purchase intentions can also be carried out with brand trust or trust in the brand of a product, so it is deemed necessary to add this variable to mediate the relationship between the use of celebrity endorsers and consumer purchase intentions by online.

\section{LITERATURE REVIEW}

Each product must have a brand or brand so that the product is known by consumers. Brand itself is a name, sign or symbol as well as a design and a combination of all of them which is intended to identify the goods or services sold by a seller and aims to differentiate him from competitors' products (Kottler \& Keller, 2013). Brands have many roles, namely offering legal protection for the unique features of a product through trademark registration, patents, helping to organize inventory and records (Kottler \& Keller, 2013).

In understanding the brand, trust in the brand is one of the benchmarks of the company. According to Gecti \& Zengin (2013), brand trust is an important mediator factor in consumer behavior before and after product purchases and this is able to generate long-term loyalty and strengthen the relationship between consumers and products. Aydin et al., (2014) revealed that trust is necessary to build and maintain healthy relationships. Cognitive trust involves good and rational reasons to believe in something including competence, reliability and predictability, while emotional trust is driven from an affectionate reaction to the attractiveness, beauty of something. Assuming that there is a relationship between the value of a brand and trust in the brand, it can be said that cognitive trust plays a more important role in influencing consumer judgment and behavior. Brand trust according to Aydin et al., (2014) consists of several components such as credibility, honesty, and benevolence. Credibility here can be interpreted as the brand's ability to meet consumer needs so that it can meet consumer expectations. Honesty is the brand's honesty in its promises and claims and the ability to keep its promises.

According to Shimp (2003: 460) celebrity endorser is using artists as advertising stars in the media, ranging from print media, social media, and television media. Not only those, celebrities used because of various attributes attached to them including attractiveness, talent, and so on. Advertising executives demand that the celebrity's image, values and 
behavior match the desired impression for the advertised brand to ensure a fit in the minds of customers by selecting various appeals in the advertisement that position the product to be considered suitable with the target market's beliefs. The products in many advertisements have the support of the most popular public figures. In addition to celebrity endorsements, products also receive support from non-celebrities. The main task of these endorsers is to create a good association between the endorser and the advertised product so that a positive attitude arises in consumers, so that advertising can also create a good image in the eyes of consumers.

The following are some celebrity roles as advertising models that can be used by the company in an advertisement (Schiffman and Kanuk 2010: 331):

- Proving (Testimonials), if a celebrity personally uses the product, he or she can provide evidence or testimony about the quality and benefits of the advertised product or brand;

- Endorsement, there are times when celebrities are asked to star in product advertisements where he is not personally an expert in the field;

- Role (Actor), celebrities are asked to promote a particular product or brand related to the role he is currently starring in a particular program;

- Spokesperson, a celebrity who promotes a product, brand or company within a certain period of time is included in the role group. Their appearance will be associated with the brand or product they represent.

Celebrities have the power to be used as a tool to persuade, seduce, and influence target consumers, namely with the fame they have and are expected to attract consumers to make purchases of the advertised products.

In choosing a celebrity who becomes an endorser, it is necessary to consider attributes/dimensions that can represent the product in question, because the suitability of the endorser's character to the product is recognized as very influential in elevating the product image, increasing sales and brand awareness. According to Shimp (2003: 468) the attributes of the endorser are:

1. Attractiveness:

a) Similarity is the audience's perception regarding the similarities they have with the endorser, this similarity can be in the form of demographic characteristics, lifestyle, personality, problems faced as shown in advertisements, and so on.

b) Familiarity, is the introduction of sources through the use of celebrity endorsers, which can be assessed based on the level of frequency of appearing in public.

c) Likeability is the audience's preference for speakers because of their attractive physical appearance, good behavior or other personal characteristics

2. Trust (Trustworthiness):

Refers to the honesty and trustworthiness of a source and being able to convince others to take the purchase intention of a product. Advertisers capitalize on the value of trust with supporters who are seen as honest and trustworthy.

3. Expertise:

Is the knowledge, skills and experience of the endorser related to the topic of the advertisement? Celebrity expertise in providing direct contact with promoted products is able to bring consumers to participate in the use of the company's products.

Types of endorsers according to Shimp (2003: 469) are divided into 3, namely:

1. Ordinary People:

Ordinary people are people who do not come from celebrities or commonly called noncelebrities but use or support a product.

2. Celebrity:

Celebrity is a person or character (actor, entertainer, singer, or athlete) who is known by the public in different fields.

3. Experts:

Experts are people whose opinions about a particular product are followed by people who do not know about the product. Usually they have an important role in word of mouth communication about a product. 
In developing a brand through marketing communication, of course, it aims to influence consumer behavior towards the product or brand. A change in consumer behavior which is the goal of product marketing is driven by consumer buying interest. From the emergence of purchase intention or interest, it will influence consumers in determining attitudes towards a brand or product which will later affect the decision to buy a product (Kottler \& Keller, 2013).

Purchase intention or intention is the driving force behind the purchase of a product (Jaafar et al, 2012). Buying interest is influenced by various considerations for the brand or product where it is influenced by factors such as interest, available information, stimulus and evaluation. These stimuli can be related to psychological factors that affect consumers such as consumer perceptions of the product or people who advertise the product in relation to endorsements (Hassan \& Jamil, 2014).

A decision involves a choice between two or more alternative courses of action. According to Kotler \& Keller (2013) the growth of consumer purchase intentions is caused by elements consisting of three stages, including:

1. Stimulation:

Stimulus is a signal that is shown to encourage or cause someone to act.

2. Awareness:

It is something that enters a person's mind. This awareness is influenced by considerations of the goods or services themselves.

3. Information Searching:

The information search aspect is divided into six parts, namely:

a) Internal information is information sourced from the memory of consumers to choose goods or services that satisfy them;

b) External information is product or service information that involves advertising (print media and direct sales, and is sourced from social or family, friends or colleagues);

c) Determine the nature of each available option. At this stage the consumer collects information related to the characteristics and characteristics of each choice. After knowing the choice, the consumer will decide which item to buy;

d) Alternative selection occurs when several products or services are a difficult choice for consumers to evaluate available alternatives;

e) Purchasing is the stage where consumers have gone through choices and are ready to spend their money in exchange for these goods or services;

f) The place where to buy is one of the developments in the store where consumers will buy the product or service. A store or dealer has a good image or stimulates consumers to shop further so that consumers are expected to become accustomed to buying at the same place.

\section{METHODS OF RESEARCH}

Based on the problems studied, the variables that exist in the study are the use of celebrity endorsers, brand trust and purchase intentions. Data collection used in this study included interviews and questionnaires. The data that has been collected will be processed using PLS. Finally, the interpretation of each variable is carried out to see the suitability of the theoretical and empirical models so that conclusions can be drawn from the formulation of the research problem.

The research location in this research is in Denpasar City. As for the object of research is the behavior of consumers in Denpasar City who intend to buy food and beverage MSME products that are influenced by Celebrity Endorser and brand trust. The population in this study is the people of Denpasar City. Determination of the sample of respondents using a non-probability sampling method with purposive sampling technique, with the criteria that consumers have a minimum of high school education because at this level of education they are considered to have good knowledge and are able to understand every question in the questionnaire and have never purchased food and beverage products. The samples in this study were 90 respondents. 


\section{RESULTS AND DISCUSSION}

Profile of the respondents based on the variables of gender, age and education completed. Judging from the gender in Table 1, the respondents in this study have the same percentage, namely $61 \%$ female and $39 \%$ male. Based on the age variable, respondents were dominated by the age of $26-34$ years as many as $53 \%, 17-25$ years as much as $30 \%$, and 35-44 years as much as 17\%. Furthermore, judging from their education, most of the respondents are in undergraduate education either currently in education or have graduated, which is $74 \%$ percent, in second place is high school education, which is $17 \%$, followed by diploma education at $9 \%$.

Validity test is used to determine whether the questionnaire is valid in data collection. In Table 1, all question items show a value of $r$-value $>$ r-table $(0.361)$ at a significance value of 5 percent. So it can be explained that all construct indicators in this study are valid, so they can be used as research instruments.

Table 1 - Results of Research Construct Validity Test

\begin{tabular}{|c|c|}
\hline Indicator & $r_{\text {-value }}$ \\
\hline $\mathrm{X}_{1.1}$ & 0,874 \\
\hline $\mathrm{X}_{1.2}$ & 0,882 \\
\hline $\mathrm{X}_{1.3}$ & 0,933 \\
\hline $\mathrm{Y}_{1.1}$ & 0,887 \\
\hline $\mathrm{Y}_{1.2}$ & 0,887 \\
\hline $\mathrm{Y}_{1.3}$ & 0,894 \\
\hline $\mathrm{Y}_{2.1}$ & 0,855 \\
\hline $\mathrm{Y}_{2.2}$ & 0,924 \\
\hline $\mathrm{Y}_{2.3}$ & 0,932 \\
\hline
\end{tabular}

Source: Primary Data, 2021.

The reliability test used Cronbach's alpha formula with a level of $=0.05$. The research instrument can be said to be reliable if the alpha value is greater than 0.60 . The following is a summary table of the reliability test results in Table 2 .

Table 2 - Research Construct Reliability Test Results

\begin{tabular}{|l|l|}
\hline Variabel & Cronbach's Alpha \\
\hline Celebrity Endorsement $\left(\mathrm{X}_{1}\right)$ & 0,877 \\
\hline Brand Trust $\left(\mathrm{Y}_{1}\right)$ & 0,846 \\
\hline Purchase Intention $\left(\mathrm{Y}_{2}\right)$ & 0,854 \\
\hline
\end{tabular}

Source: Primary Data, 2021.

Based on Table 2, all construct indicators show Cronbach's alpha value $>0.60$, it can be explained that all construct indicators in this study are reliable and feasible to be used as instruments.

\section{DISCUSSION OF RESULTS}

This study uses a Partial Least Square (PLS) analysis approach to test and analyze the research hypotheses that have been stated previously where it was found the results of data processing that Celebrity Endorsements (X1) have a correlation with Purchase Intention (Y2) of 0.413 and a correlation with Brand Trust (Y1) of 0.644 . Brand Trust (Y1) has a correlation with Purchase Intention (Y2) of 0.542 .

The effect of Celebrity Endorsement (X1) on Purchase Intention (Y2) produces a path coefficient value of 0.413 . The value of $t$ Statistics is 5.015 ( $>t$ critical 1.96), then Celebrity Endorsement on Purchase Intention is significant. Based on these results, hypothesis $1(\mathrm{H} 1)$ which states that Celebrity Endorsement has a positive and significant effect on Purchase Intention is accepted. This means that the better the role of Celebrity Endorsements, the higher the intention to buy food and beverage MSME products. The results of this study are supported by previous research from Hassan and Jamil (2014) in their research which 
revealed that there is celebrity involvement in advertising in the current competitive marketing era to create strong recognition and perception of the product. In this study, the focus is on examining the use of celebrities in endorsements to determine their effect on consumer purchase intentions where the use of celebrities involves several attributes that become the criteria for evaluating celebrities themselves from the consumer's point of view.

The effect of Celebrity Endorsement (X1) on Brand Trust (Y1) in Table 5.7 produces a path coefficient value of 0.644 . The value of $t$ Statistics is 14,762 ( $>t$ critical 1,96$)$, then Celebrity Endorsement to Brand Trust is significant. Based on these results, hypothesis 2 $(\mathrm{H} 2)$ which states that Celebrity Endorsement has a positive and significant effect on Brand Trust is accepted. This means that the better the role of Celebrity Endorsements, the higher the level of trust in food and beverage MSME products. The results of this study are supported by previous research by Jennifer N.G in 2016. In this study, it is known that consumer perceptions of celebrity endorsers have a significant effect on brand trust from products marketed through Instagram social media.

The effect of Brand Trust (Y1) on Purchase Intention (Y2) produces a path coefficient value of 0.542 . The value of $t$ Statistics is 6.442 ( $>t$ critical 1.96), then Brand Trust on Purchase Intention is significant. Based on these results, hypothesis $3(\mathrm{H} 3)$ which states that Brand Trust has a positive and significant effect on Purchase Intention is accepted. This means that the higher the trust in the brand, the higher the intention to buy food and beverage MSME products. The results of this study are supported by previous research by Che-Hui Lien et al in 2015. In this study, it is known that to increase online purchasing preferences, especially hotels, there are several considerations, namely brand image, price, trust, and value to be able to influence the purchase intention of consumers. From this research, it can be seen that brand image and trust are determinants in influencing the purchase intention of consumers.

To test the indirect effect of Brand Trust in mediating the relationship between the use of Celebrity Endorser and Purchase Intentions, the Sobel test was conducted. Based on the results of the PLS output, it is found that the coefficient of $a$ is 0.644 and the coefficient of $b$ is 0.542 . The standard error value of coefficient $a$ is 0.044 and the standard error coefficient $\mathrm{b}$ is 0.084 , so it can be entered into the following Sobel test formula:

$$
Z=\frac{a b}{\sqrt{b^{2} S E_{a}^{2}+a^{2} S E_{b}^{2}}}=5,908
$$

Based on the results of the Sobel test in the above calculation, it shows that the result of the $Z$ value $=5.908$, is greater than the t-table, which is 1.96 . These results explain that Brand Trust is able to mediate the influence of Celebrity Endorsements on Purchase Intentions. In this case, to increase the influence of Celebrity Endorsements on purchase intentions, it is necessary to focus on trust in the brand, because by increasing trust in the brand, the intention to make a purchase.

\section{CONCLUSION}

Celebrity Endorsement on Purchase Intention has a positive and significant effect. This means that the better the role of Celebrity Endorsements, the higher the intention to buy food and beverage MSME products.

Celebrity Endorsement on Brand Trust has a positive and significant effect. This means that the better the role of Celebrity Endorsements, the higher the level of trust in food and beverage MSME products.

Brand Trust on Purchase Intention has a positive and significant effect. This means that the higher the trust in the brand, the higher the intention to buy food and beverage MSME products.

Brand Trust is able to mediate the influence of Celebrity Endorsements on Purchase Intentions. In this case, to increase the influence of Celebrity Endorsements on purchase 
intentions, it is necessary to focus on trust in the brand, because by increasing trust in the brand, the intention to make a purchase will also increase.

Based on the results of the analysis and conclusions, the suggestions that can be given to those in need are as follows:

- In marketing their products, MSME actors are expected to maximize the use of Celebrity Endorser as a marketing strategy to be able to convince and increase the purchase intention of consumers who previously were hesitant to buy food and beverage products online and increase trust in brands. With an increase in consumer buying intentions, it is also hoped that MSME actors who sell food and beverages online can increase their sales turnover significantly;

- Future research needs to expand the geographical scope of the research so that it is not limited to Denpasar City.

\section{REFERENCES}

1. Antara, Satriawan, Sukaatmaja, Rimbawan, Tuningrat. 2011. Pengembangan Komoditas/Produk/ Jenis Usaha Unggulan Umkm Di Provinsi Bali. Denpasar, Bali.

2. Aydin, Gulnil, et al., 2014. The Role of Brand Trust on Parent's Purchase Intentions of Baby-Care Products. Dogus University Journal. Vol 15. Issue 2: 165-180.

3. Che-Hui Lien,et al., 2015. Online hotel booking: The effects of brand image, price, trust and value on purchase intentions. Asia Pacific Management Journal.

4. Gecti, Fatih and Zengin, Hayrettin. 2013. The Relationship between Brand Trust, Brand Affect, Attitudinal Loyalty and Behavioral Loyalty: A Field Study towards Sport Shoe Consumer in Turkey. International Journal of Marketing Studies. Vol 5. No.2:111-119.

5. Jaafar, S.N., et al. 2012. Consumers' Perception, Attitudes, and Purchase Intention towards Private Label Food Products in Malaysia. Asian Journal of Business and Management Sciences. Vol 2. No.8:73-90.

6. Jennifer,N.G. 2016. Pengaruh Endorser Selebriti Terhadap Brand Image, Brand Trust Dan Minat Beli Konsumen Pada Media Sosial Instagram (Studi Kasus Produk Allure Vanilla Green Tea Latte). Tesis. Repository Universitas Airlangga.

7. Hassan, S.R. and Jamil, R. Ahmed. 2014. Influence of Celebrity Endorsement on Consumer Purchase Intention for Existing Product: A Comparative Study. Journal of Management Info. Vol 4(1): 1-23.

8. Kotler, Philip Dan Kevin Lane Keller. 2013. Manajemen Pemasaran. Edisi 13 Jilid satu. Erlangga: Jakarta.

9. Schiffman, L.G., \& Kanuk, L.L. 2010. Consumer Behaviour (10th ed). New Jersey, Pearson Prentice Hall.

10. Shimp,Terence. 2003. Periklanan Promosi \& Aspek Tambahan Komunikasi Pemasaran Terpadu. Jilid I. Edisi 5, Jakarta: Erlangga.

11. Sumartini. Mandasari. 2020. The Effect of Celebrity Endorser on the Customer's Online Purchase Intention. Proceeding. Https://eudl.eu/proceedings/wards/2020.

12. Zuari, F.O., H. Widayani dan R.D. Daniel. 2013. Pengaruh Strategi Pemasaran Terhadap Penerimaan Bersih Restoran Omah Pincuk. Proceeding PESAT, Vol. 5, hal. E-383 - E389. ISSN: 1858-2559. 